\title{
The Energy Crisis and Environmental Concerns in Sub-Saharan Africa (Nigeria): A Perspective on Public Governance for Climate Action
}

\author{
Abdulhamid Ozohu-Suleiman, Ph.D. \\ Professor of Public Policy Analysis \& Governance \\ Department of Public Administration \\ University of Abuja, Nigeria
}

Received: Jan. 24, 2021 Accepted: Mar. 25, $2021 \quad$ Online published: Apr. 18, 2021

doi:10.5296/jpag.v11i2.18242ＵRL: https://doi.org/10.5296/jpag.v11i2.18242

\begin{abstract}
The inextricable relationship between environment and development is unarguable, and the literature is replete with scientific evidence of the interdependence between the two phenomena. However, as the interaction between man and nature proceeded from the condition of conviviality to that of belligerence, there has been a marked decline in the resilience of nature to accommodate human avarice. It is nature's reactions to this unfair transaction that is today called climate change. In Sub-Saharan Africa, climate change remains an intractable problem, or to borrow the words of Pollitt (2016), "a very wicked issue" that challenges state capacity to contain its scourge. Finding a way around this wicked issue has been the preoccupation of public policy scholars and practitioners. Incidentally, combating climate change is a cross cutting issue in the 2030 global agenda for sustainable development which inevitably touches on access to affordable and sustainable energy, protection of the ecosystem to halt biodiversity loss. Consistent with this global agenda is the Africa agenda 2063 with the overarching aspiration of "a prosperous Africa based on inclusive growth and sustainable development". These multinational initiatives suggest a growing consensus on environmental sustainability as the desideratum of development. In Nigeria, the energy crisis and its attendant consequences on the environment has made the country one of the most vulnerable to climate change in the region. This paper seeks to offer a perspective on public governance for climate action. It argues that lack of state capacity to address the energy requirement of the economy has had grave consequences on environmental resourcefulness. While consensus on multinational agenda is given, the point at issues is for national governments to domesticate this agenda and mobilize the requisite resources to translate them into measurable achievements. The paper observes that apart from
\end{abstract}


the huge deficit in furnishing the energy need of the real sector, the energy crisis poses existential threats such as food insecurity, environmental pollution/degradation through deforestation, flooding and pollution. The paper recommends, among others, that the Nigeria-Germany bilateral cooperation on the power sector should be implemented to its logical conclusion, and that a program of public enlightenment is urgently required to arrest traditional practices that are harmful to environmental sustainability.

Keyword: climate change, development, environment, energy, economy, governance, public policy

\section{Introduction}

The relationship between the environment and development can best be described as two sides of the same coin. This vivid analogy underscores the interdependence between the two, such that they thrive on a mutually reinforcing condition. From the earliest time of human existence when man survived entirely on subsistence hunting and gathering up to the present time of high tech inventions, the environment has kept faith with man's ceaseless adventure to explore its resourcefulness. Thus, the entire breakthrough in technology; beginning with the first industrial revolution (mechanical) of the seventeenth century, through the second (oil and electrical) of the twentieth century, and the third (info-tech) in the last quarter of the twentieth century to the fourth industrial revolution (artificial intelligence) of the twenty first century, have all been achieved by mankind on the turf of a resilient environment that underpins human progress. However, as technology improves human capacity to continue in this exploit, the age-long relationship between man and nature proceeded from the condition of conviviality to that of belligerence - a condition that signaled the beginning of declining resilience of nature to accommodate man's avarice. What is today called climate change is nature's reactions to the unfair transactions between man and his environment.

Although technology has come handy to mitigate and adapt to climate change, the benefits are disproportionately skewed in favor of the industrialized economies of the global north while the developing nations of Africa remain the most vulnerable to the grave consequence of climate change. In the global north, technology is both a cause and an antidote to climate change. In the global South (especially the relatively weak economies of Sub-Saharan Africa), climate change remains an intractable problem, or to borrow the words of Pollitt (2016), "a very wicked issue" that compromise development and social progress. Finding a way around this wicked issue and its consequences has been the preoccupation of public policy scholars and practitioners in the last couple of decades. Incidentally, combating climate change is a cross cutting issue in the 2030 global agenda for Sustainable Development Goals (SDGs) which inevitably touches on access to affordable and sustainable energy, protection of the ecosystem to halt biodiversity loss - all of which are to be achieved by strengthening global partnership to improve state capacity across continents. Consistent with the SDGs is the Africa Agenda 2063 with the overarching aspiration of a prosperous Africa based on inclusive growth and sustainable development. These laudable multinational initiatives suggest a growing consensus on environmental resourcefulness as the desideratum of sustainable development. However, while consensus on multinational agenda is desirable and 
therefore given, the point at issues is for national governments to domesticate these agenda and mobilize the requisite resources to translate them into measurable achievements. It is at this point that country-specific checks in progress is often characterized by a mixed bag of experience.

In Nigeria, public governance for climate action remains a vexed issue characterized by increasing lack of state capacity to mobilize action and resources to confront the menace. With an estimated population of over 200 million people, Nigeria is host to about $20 \%$ of black people in Sub-Saharan African (Worldometers, 2020) that are at the mercy of the scourges of climate change. While environmental concerns are multidimensional in Africa, the energy crisis and its predictable consequences on the environment, poses existential threats such as food insecurity, pollution and deforestation. With an annual population growth rate of $2.58 \%$ (Worldometers, 2019), Nigeria requires a corresponding improvement in food production to support the exponential growth in population. This depends not only on state capacity to develop the agricultural sector, but more largely on the resourcefulness of the environment (land, water, forest reserve and climatic condition) to sustain food production. Moreover, the energy deficit which compels the critical mass of the citizens to engage in practices that are harmful to the environment, provides the recipe for pollution and deforestation with severe consequences on environmental resourcefulness.

Thus, the energy crisis more than any other climate change inducing factor, has the most significant impact on the cross cutting issues of environment and development in Nigeria. In the light of this observation, the paper seeks to examine the impact of the energy crisis on environmental sustainability in Nigeria. The study is undertaken within the framework of public governance for climate action and its implications for citizen existential conditions. The paper is organized into seven sections. Section one is the introduction which provides some background information and reflections on the subject matter of the paper. Section two articulates the objectives and describes the methodology of the study. Section three presents a brief outlook of the Nigerian economy (with particular emphasis on the energy profile and the negative development statistics it has engendered). Section four is on the environment of climate change which presents the concrete manifestations of climate change and its consuming impact on human existential conditions. Section five examines Nigeria in the context of multinational framework of intervention. Section six discusses issues of public governance for climate action in relation to energy provision and its consequences on food security, environmental pollution and deforestation. Sections seven provides the concluding remarks and recommendations.

\section{Objectives/Methodology of Study}

Although the Africa Agenda 2063 on environment and resilient economies has articulated a number of unambiguous priority areas, building state capacity for public governance for climate action remains a salient issue in public policy dialogue that beckons on intellectuals to evaluate state action in specific areas of interest. To this end, the major objective of this paper is to articulate a perspective on public governance for climate action in Nigeria. The specific objectives are: (i) to examine public governance of the energy sector; (ii) examine 
the impact of energy deficit on environmental resourcefulness; and (iii) to offer policy recommendations towards improved mitigation and adaptation in Nigeria. To realize these objectives, the paper adopts a methodology that is both descriptive and analytical. This approach relies on official records and a considerable volume of related literature. In respect of official records, the study examines: (i) The National Environmental Standards and Regulations Enforcement Agency (NESREA) Act; (ii) The reform of Nigeria power sector; (iii) The United Nations Sustainable Development Goals (SDGs); (iv) The Africa Agenda 2063 (First Ten-Year Implementation Plan 2014-2023); and (v) The African Development Bank Report on Infrastructure Action Plan for Nigeria. The review of literature considers a wide range of scholarly perspectives on the subject matter of study.

\section{The Nigerian Economy and Energy Deficit}

Any meaningful reflections on current trends in the Nigerian economy in the context of her energy crisis must proceed from a continental outlook to country-specific overview. This approach arguably underscores the significance of the Nigerian economy to the development prospects of the African continent. However, only a sparing highlight of these continental/regional outlook will suffice to provide a macro picture as background to a more detailed account of current trends in Nigeria. The country-specific outlook is instructive to the extent that it accentuates the energy deficit as the most critical factor in the development problematics of Nigeria. Although, energy provision involves cross cutting requirements, the issue under consideration is limited to checks in access to renewable energy for industrial and domestic consumption. While the provision of renewable energy or the lack of it at the level of industry impacts on the real and informal sector and therefore determine the level of economic development, the same scenario at the level of domestic consumption also impacts on household and determine citizens' quality of life.

We begin by acknowledging that Africa is the second largest and most populous continent on earth. The continent is home to over 1.3 billion people representing $16.72 \%$ of the world population (Worldometer, 2020). The continent is reputed to have the youngest population with $41 \%$ of her men and women under the age of 15 years. Out of the 54 countries in Africa, Sub-Saharan Africa has 46 with a population size of approximately 1.1 billion people (Worldometer, 2020). Apart from this huge population size, Sub-Saharan Africa is blessed with a variety of natural resources. The list (which is by no means exhaustive), include; crude oil, diamond, gold, iron, cobalt, uranium, copper, bauxite, silver, petroleum, cocoa beans, limestone, coal, tin, woods, arable land, and coastal zones across the continent. These resource endowments are a source of hope and despair. Hope, because in these resources lie a huge prospect for sustainable development, and despair, because these resource endowments are the very reason for which the new scramble for Africa has generated a lot of foreboding (Cassanova, 2004; Jinadu, 2010; Nwoke, 2010 \& Alli, 2010).

Thus, the bad news is that these natural resources are either largely not harnessed owing to poor technological capacity or at best are ferried abroad to feed the industrialized economies of Europe and North America, leaving the economies of Africa in a parlous state. With an average life expectancy of 52 years and an estimated GDP growth of 3.9\% in 2020 and GDP 
per capita of 1,970USD, Africa is home to the largest number of poor people on earth (AFDB, 2020). Extremely limited access to energy remains the most fundamental economic indicator that extenuate development and by extension the quality of life. Although Africa has enormous renewable energy resources, she has only 50 gigawatts $(\mathrm{GW})$ of renewable energy capacity, mostly hydropower of 36GW (Africa Energy outlook 2019). As at 2018, the energy consumption per capita and population in Sub-Saharan Africa was below the average for developing countries. Figure 1 below illustrates the details.

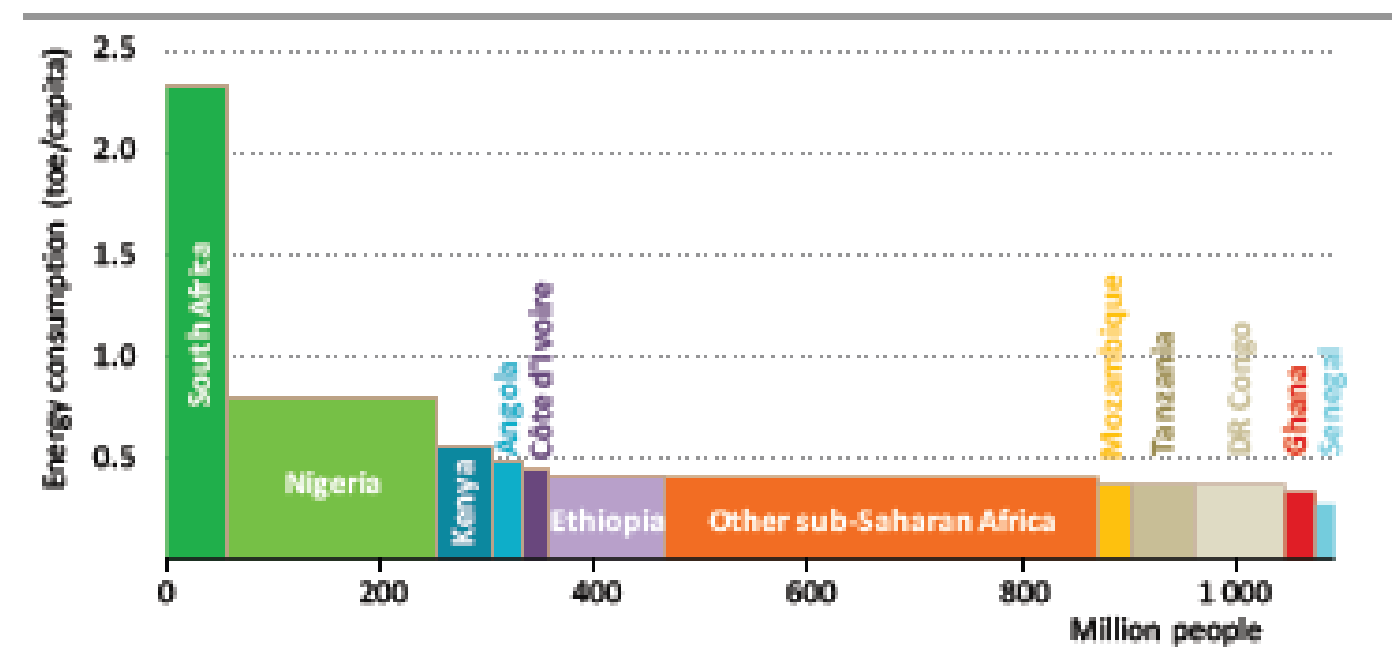

Figure 1. Energy consumption per capita and population in selected Sub-Saharan African countries 2018

Source: Africa Energy Outlook. (www.iea.org/africa2019)

With the Exception of South Africa, the energy consumption per capita of other countries in Sub-Saharan Africa is about $65 \%$ which is below the average for developing countries. In the case of South Africa, her renewable energy consumption record is relative to her population size of 57.78 million people. Nigeria with $2.64 \%$ share of world population and a GDP of USD 450 billion is the largest economy in Africa while South Africa trails behind with a GDP of USD 372 billion (http://www.Bloomberg.com/africa). With a maximum crude oil production capacity put at 2.5 million barrels per day, Nigeria ranks as Africa's largest oil producing country in the world. Crude oil production was reported at $1,853.000 \mathrm{barrel} / \mathrm{day}$ in the month of March, 2020. This record is an increase from the previous number of $1,788.000$ barrel/day in the month of February, 2020 (ceicdata.com).

Despite these strong fundamentals, the development of Nigeria has been held down by a huge gap in infrastructure that underpins development. Renewable energy provision is unarguably a critical component of this underpinning infrastructure. Figure 2 and Table 1 below indicate trends in actual and projected poverty rate and real GDP per capita and the statistical projection respectively in Nigeria 


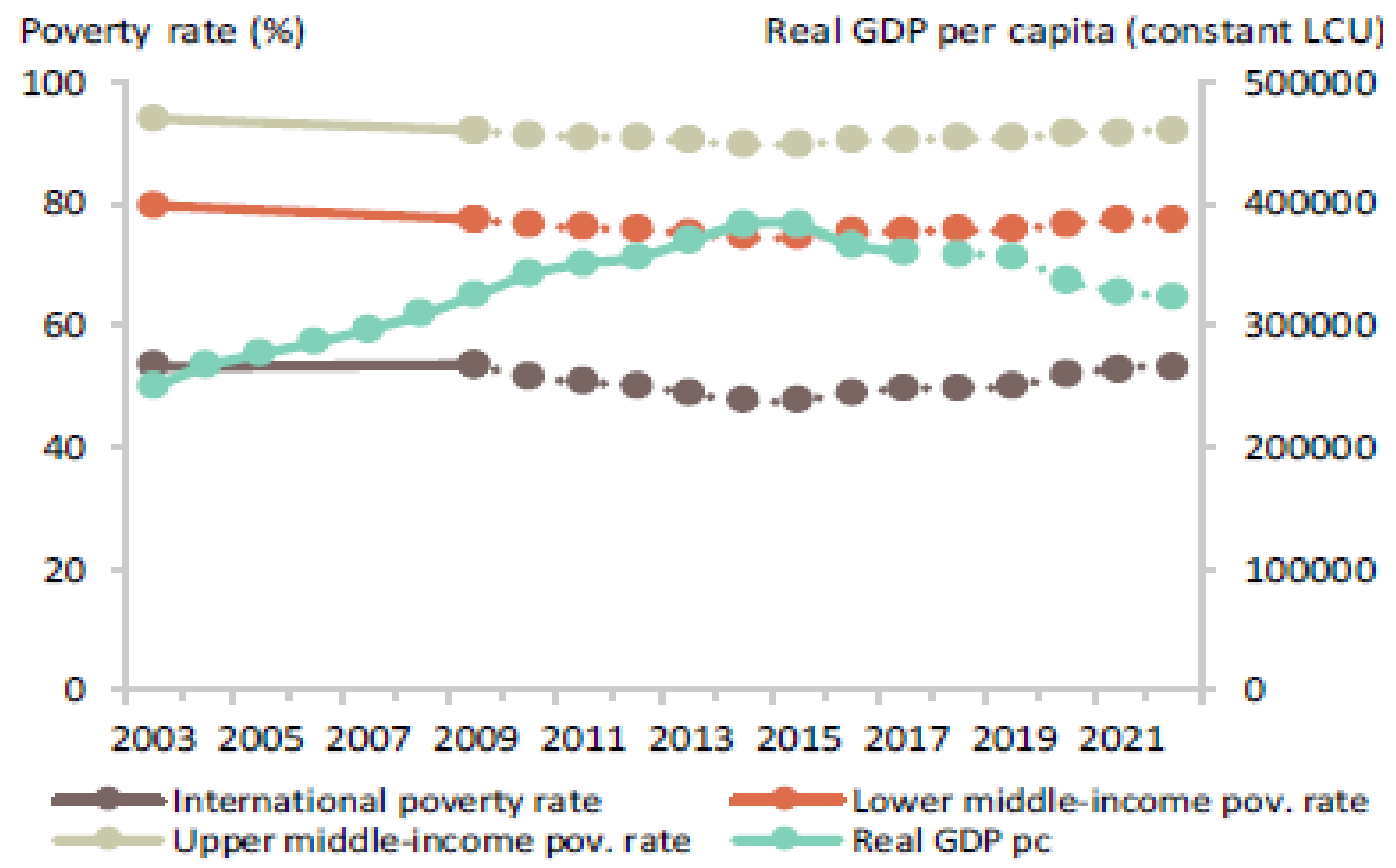

Figure 2. Actual and Projected poverty rates and real GDP per capita in Nigeria

Source: (https://www.ceicdata.com/en/indicator/nigeria/gdp-per-capita)

Notes: see table 2.

Table 1. Actual and Projected percentage change in poverty outlook (using annualized elasticity with pass through $=0.7$ based on GDP per capita in constant LCU)

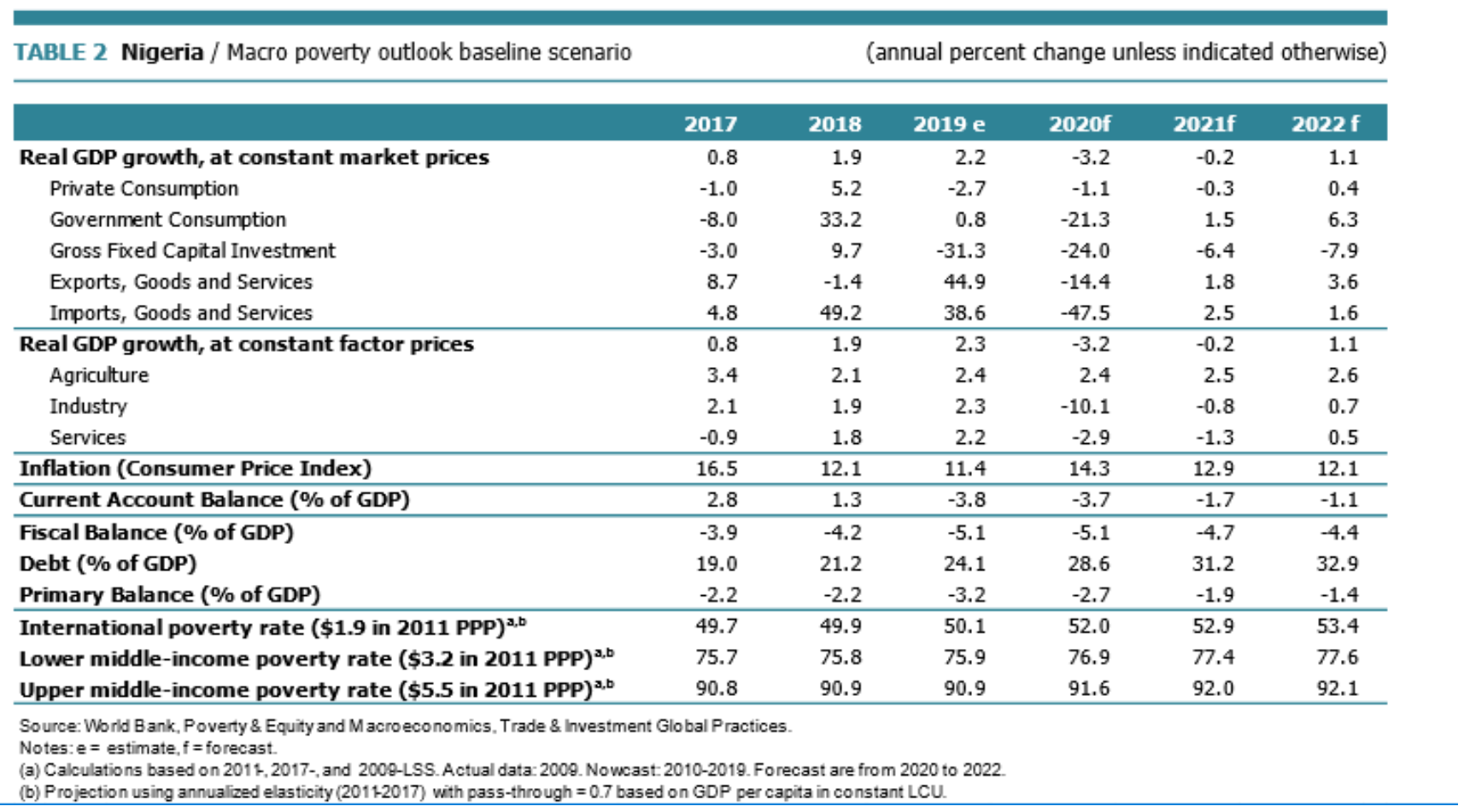




\section{Mll Macrothink}

Journal of Public Administration and Governance

ISSN 2161-7104

2021, Vol. 11, No. 2

The current efforts to diversify the economy away from dependence on oil, largely on account of the uncertainties in the price of crude at the international market (which plummeted from USD 63.83 as at January,2020 to about USD 20 in March, 2020) in the wake of the COVID 19 pandemic, is severely hampered by infrastructure deficit. For example, renewable energy constitutes an enabling infrastructure in the implementation of the agricultural promotion policy also known as "Green Alternative" as part of the economic diversification drive. Progress checks on the policy implementation reveal that investment inflows into infrastructure and midstream logistic e.g. warehouse, storage, processing systems, remain rudimentary (APP factsheet, 2017). This is due largely to inadequate energy provision and the huge cost associated with alternative power source. Access rate to power is currently put at $45 \%$. Although Nigeria is projected to attain universal access to power by 2030, there are currently over 20 million households without access to power (USAID, 2020).

The increasing demand for usable energy in Nigeria (like any other developing economy), is driven by two compelling conditions. The first is the annual percentage change in population which is currently put at $2.54 \%$ (2018 estimate). The second is the pressure that is brought to bear on energy consumption for economic activities. Based on these conditions, energy consumption can further be categorized into industrial, transport, agricultural, commercial (including a number of the service sector), and household. While household accounts for about 65\% share of energy usage (Oyedepo, 2012), the remaining share available to the other sectors is an indication of how much the energy deficit contributes to the crisis of development in Nigeria. The share of energy consumption for economic activities has a direct relationship with the overall development of a country, such that a pattern of energy consumption that is skewed in favor of household does not necessarily add up to citizens' quality of life. This is because energy is also required to provide socio-economic infrastructure that underpins a comfortable life for the citizens. For example, the construction industry requires energy for municipal facilities and urban renewal projects; energy is required to construct and operate dams for the supply of portable water, and energy provision is fundamental to well-functioning education and health sectors. For Nigeria, the inability to strike a balance between the energy needs of the household and what is required to grow the economy lies at the heart of the energy crisis. Oydedpo observe that:

Energy and poverty reduction are not only closely connected with each other, but also with the socio-economic development, which involves productivity, income growth, education and health... The energy crisis, which has engulfed Nigeria... has... largely contributed to the incidence of poverty by paralyzing industrial and commercial activities (Oyedepo, 2012:2). 
Table 2 below indicates trends in demand and supply of electricity in Nigeria between 2010 and 2020, and projecting into 2030 .

Table 2. Electric power capacity (Demand \& Supply 2010-2030)

\begin{tabular}{|c|c|c|c|c|c|c|c|c|c|c|c|c|}
\hline \multicolumn{13}{|c|}{ Electric power demand } \\
\hline \multirow[b]{3}{*}{ Fuel type } & \multicolumn{4}{|c|}{2010} & \multicolumn{4}{|c|}{2020} & \multicolumn{4}{|c|}{2030} \\
\hline & \multicolumn{2}{|c|}{ Demand (MW\%) } & \multicolumn{2}{|c|}{ Supply (MW\%) } & \multicolumn{2}{|c|}{ Demand (MW\%) } & \multicolumn{2}{|c|}{ Supply (MW\%) } & \multicolumn{2}{|c|}{ Demand (MW\%) } & \multicolumn{2}{|c|}{ Supply (MW \%) } \\
\hline & 7 & 13 & 7 & 13 & 7 & 13 & 7 & 13 & 7 & 13 & 7 & 13 \\
\hline Coal & & & 0 & 0 & & & 6.515 & 16.913 & & & 15.815 & 63.896 \\
\hline Gas & & & 13.555 & 31.935 & & & 37.733 & 78.717 & & & 85.585 & 192.895 \\
\hline Hydro & & & 3.702 & 3.902 & & & 6.479 & 6.749 & & & 11.479 & 11.479 \\
\hline Nuclear & & & 0 & 0 & & & 3.530 & 11.005 & & & 11.872 & 36.891 \\
\hline Small-hydro & & & 40 & 208 & & & 140 & 1.000 & & & 701 & 2.353 \\
\hline Solar & & & 5 & 30 & & & 34 & 750 & & & 302 & 4.610 \\
\hline Wind & & & 0 & 500 & & & 1.471 & 3.791 & & & 5.369 & 15.567 \\
\hline Total & 15.730 & 33.250 & 17.303 & 36.576 & 50.820 & 107.600 & 55.903 & 118.836 & 119.200 & 297.900 & 131.122 & 327.690 \\
\hline
\end{tabular}

Supply by fuel mix and demand for $7 \%$ and $13 \%$ GDP growth. Adapted from ECN [44,A6].

Source: Adapted from Oyedepo, S. O (2012), Energy and Sustainability in Nigeria: The Way Forward (http://www.energsustainsoc.com/content/2/1/15)

There has been a huge discrepancy between installed generating capacity and actual output of electric power. Nigeria currently has $12,500 \mathrm{MW}$ of installed generating capacity. This generating capacity depends on hydro power (12.5\%) and fossil fuel (87.5\%). However, actual output of energy available for consumption is between $3,500 \mathrm{MW}$ and $5,000 \mathrm{MW}$

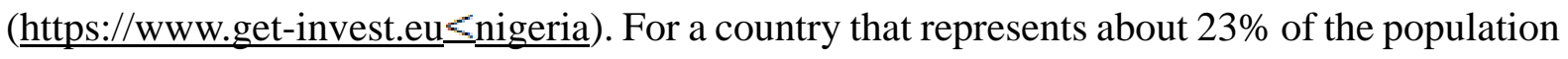
of Sub-Saharan Africa, the quoted figure on installed capacity is inadequate, let alone the figure that is available for consumption. A number of structural problems are associated with these unimpressive figures. These include seasonal drought, which creates uncertainty in the output of hydro plants, continual loss of water that reduces potential energy that can be harnessed from the rivers, and decades of gas flaring which burns off valuable fuel that would have been converted into energy (Kennedy-Darling, Hoyt, Muaro and Ross, 2008). It is instructive to note that these structural problems are induced by climate change. Seasonal drought occasioned by climate change is drying up surface water available for hydro power generation. There is also a phenomenal decrease in the strength of water flow from the river no thanks to climate change. Decades of gas flaring in the process of crude oil exploration and refining remains a sad commentary on the poor technological capacity of Nigeria. Thus, gas flared into the atmosphere is perhaps the highest contributor to greenhouse emission that is partly responsible for global warming and environmental pollution.

\section{The Environment of Climate Change}

We have observed earlier in the paper that environment is the turf that underpins human 
progress. The increasing change in climatic conditions are equally manifested on the same turf that has supported livelihood and facilitated development over the centuries. The apparent zero sum game that characterize the interaction between the environment and technology has led man to claim dominion over nature. However, the increasing existential threats of climate change are indications that man's dominion over nature is overextended and at best ephemeral. Climate change has and will continue to have wide ranging effects on socio-economic and related sectors; water resources, agriculture, food security, human health, terrestrial ecosystems, bio-diversity and coastal zones (UNFCCC, 2007). Although nature's fury represents a clear message on the urgent need for mitigation and adaptation, the unequal share of technological capacity between the industrialized countries and the developing nations, especially in Sub-Saharan Africa, has to a large extent exacerbated climate change on the environment of the latter.

Thus, the use of technology to sustain industrial economies generates consequences that impact on the wellbeing of co-inhabitants of the planet earth in Sub-Saharan Africa. To date, industrialized countries account for roughly $80 \%$ carbon-dioxide buildup in the atmosphere. Annually, more than $60 \%$ of global industrial carbon-dioxide emission originates from the industrial complex of advanced economies, where only about $20 \%$ of the world population resides (Mgbemene, Nnaji and Nwozor, 2016). However, as nature and man spoil for an edge in this battle of attrition, it is obvious that irrespective of geographical location of human habitation, man is perhaps living on borrowed time. It was reported that:

The major impacts and threats of global warming are widespread. Increasing ocean temperatures cause thermal expansion of the oceans and in combination with melt water from land-based ice is causing a sea level rise...Increasing melting of sea ice and fresh water influx from melting glaciers and ice sheet also has potential influence on global pattern of ocean circulation (UNEP, 2018).

In Nigeria, as climate change persists, the impacts on the environment are mounting, and any attempt to capture all of them in a discussion can be frightening. However, a few of them will suffice here. There is increasing loss of biodiversity that threatens food security, receding forest reserves that escalates deforestation, loss of farmlands, ozone depletion and increase in carbon emission that precipitates pollution and compromise human health. In many part of the country, the combined effect of flooding, drought, and gully erosion have severely extenuated farming activities. There is uncertainty about what to plant, where and when due to the unpredictable weather conditions (especially variability in rainfall). Droughts have largely occurred in the north western and north eastern parts of Nigeria. Gully erosion is a common feature of climate change in the south east that often sacks communities and destroys farmsteads. Flooding occasioned by excessive rainfall during the peak of the season uproots human settlements and washes away farmlands in the south-south and parts of the north-central regions of the country. Environmental pollution is more common in urban settlements. We have gas flaring and other oil exploration related pollution in the Niger-Delta. 


\section{Ml Macrothink}

Journal of Public Administration and Governance

ISSN 2161-7104

2021, Vol. 11, No. 2

The use of generating plants as alternative source of energy (which is a common practice in businesses and households) has contributed its fair share of pollutant into the atmosphere.

It is estimated that Nigeria losses about \$5billion every year due to drought and desert encroachment (World Bank, 2005). Persistent shortfall in rain, bush burning, over harvesting, livestock grazing, logging and desert encroachment are the major causes of drought and deforestation in northern Nigeria (Hassan and Oloke, 2019). Over harvesting and overgrazing are degrading about 35,000 hectares of land each year. The northern region affected stretches from Lake Chad in the east to River Niger in the west, covering a distance of about $1.500 \mathrm{~km}$ over varied formations and habitats (FME, 2018) The net effects of drought and deforestation are drop in agricultural production, livestock mortality and general food scarcity.

Flooding which was hitherto a common climatic occurrence in the south-south and parts of the north-central regions, has been recorded across the six geo-political zones in recent times. Although several factors interact to cause the recent yearly occurrences of flooding in Nigeria, climate change which has created significant distortion in the pattern and intensity of rainfall is most responsible (Umana 2019). The devastating effects of flooding include loss of lives and livelihood, and destruction of critical infrastructure (like communications, electricity and water facilities), just to mention a few. It was reported that in 2018, over 1 million people were affected by flood across 12 states in Nigeria. Flash flooding reoccurred in 2019 that affected Adamawa, Borno and Yobe states. The flood further displaced over 600 Internally Displaced Persons (IDP) camps, host communities, farmland and farm produce (the Guardian, 2019). The Red Cross reported that from June, 2019 to the end of the season, torrential rainfalls and flash floods hit 124 Local Government Areas across the 36 states of the federation (including the Federal Capital Territory). This took its toll on a total of 210,117 people with 171 casualties recorded and 130,610 people displaced (floodlist.com/Africa/ng).

Climate change arising from air pollution is mostly associated with human and industrial triggers. In Nigeria, human triggers include such activities as the use of fuel wood for cooking, bush burning and the use of generating plants as alternative source of energy for domestic purpose. The industrial triggers include manufacturing activities, gas flaring from oil exploration, refining and related activities. While the human triggers are increasingly becoming a source of health hazard, they are largely part of the consequences of the energy deficit in Nigeria. The industrial triggers (particularly oil exploration and refining) constitute the most significant source of air pollution. Household dependence on fuel wood for energy accounts for the change in the country's vegetation and increase in deforestation. A report by the European Union under the Nigerian Energy Support Program (NESP) observes that: 


\begin{abstract}
About $69.8 \%$ of Nigeria's population depends on fuel wood for domestic and cottage industry purposes, those using fuel wood for energy purposes are consuming about $3.3 \mathrm{~m}^{3}$ of wood a year. This situation is compounded by the predominant use of inefficient cooking methods, based largely on open fire with obviously low thermal efficiency and associated smoke related ailment, especially among women and children (EU:NESP,
\end{abstract}

The use of generating set as alternative source of energy (which is a common practice among Nigerians) has added to the vulnerability of households to the hazards of pollution. It was estimated that out of the 16.4 million rural households in Nigeria, only about 4.6 million are connected to the national grid (Punch, 2017). In the same vein, GIZ, a German Development Agency, in a report entitled: "Promoting Clean Energy Investments in Nigeria", noted that about $86 \%$ of the companies in Nigeria own or share a generator and about $48 \%$ of their total energy need is covered by these private generators (punch, 2017). Between 2008 and 2014, about 10,000 Nigerians died from poisonous generator fumes (Vanguard, 2014). Given that no significant improvement has been made in stable power supply from the national grid, the health of millions of Nigerians is increasingly being compromised by poisonous fumes from widespread use of generating set.

Closely related to the foregoing is decades of environmental degradation arising from oil exploration and refining in the Niger Delta. Industrial waste, gas flares, fire disaster and acid rain have severally and in combination led to significant loss of bio-diversity and by extension affected the health and threatened the livelihood of inhabitants of the Niger Delta. For example, a United Nations report on the extent of environmental pollution in Ogoniland noted that the community is exposed to hydrocarbons every day through multiple channels. While the impact of individual polluted land sites tends to be localized, air pollution related to oil industry operation is widespread, affecting the quality of lives of about one million people (UNEP, 2017). The widespread nature of air pollution from gas flare was corroborated in a satellite data estimates from the Federal Ministry of Environment when it reported that oil companies flare over 313 million standard cubic feet of gas annually. This translates to carbon emission of 16.5 million tones (Punch, 2020). Human exposures to this pollutant are not unconnected to common health conditions such as cancer, neurological and reproductive disorder, lung damage and skin infection (Ajugwo, 2013).

\title{
Nigeria in the Context of Multinational Framework of Intervention
}

The paper has argued from the onset that, though multinational initiatives are a sine qua non to address climate change, more fundamental is the preparedness of national stakeholders to domesticate these initiatives and mobilize action and resources for adaptation and mitigation in their respective countries. In assessing the level of preparedness of Nigeria, it is imperative to undertake a cursory check on the legal and the institutional frameworks of public governance for climate action. These frameworks demonstrate the extent of understanding 
and commitment of the Nigerian government to the global perspective on mitigation and adaptation.

Before this check, it is helpful to first highlight the salient points of these multinational initiatives. We have the Sustainable Development Goals (SDGs) and the Africa Agenda 2063. The SDGs is a global plan of action for people, planet and prosperity with 17 goals and 169 targets. Goals 7, 13, 14 and 15 are severally and in their combination, articulated to address the cross-cutting issues of climate change. These goals underscore the determination of World leaders to protect the planet from "degradation, including through sustainable consumption and production, sustainably managing natural resources and taking urgent action on climate change, so that it can support the needs of the present and future generations" (SDGs, 2015:1). World leaders also recognize that this commitment can only be achieved through global partnership across continents. To this end, goal 17 which seeks to strengthen the means of implementation and revitalize the global partnership for sustainable development is unequivocal.

Secondly, the Africa Agenda 2063 is a continental plan of action with the overarching aspiration of a prosperous Africa based on inclusive growth and sustainable development. In the first ten-year implementation plan (2014-2023), the African Union Commission published a report which clearly highlights the goals and priority areas for the plan period. Goal 7 is on environment and climate resilient economies with corresponding priority areas of: Bio-diversity; Conservation and sustainable natural resources management; Water security; Climate resilience and natural disaster preparedness and prevention; and Renewable energy (AU Commission, 2015). Apart from providing a broad policy direction on the basis of which National stakeholders can proceed to articulate their specific policy framework of intervention, these multinational initiatives underscore the existential threat of climate change to humanity- one that put to test the widely publicized purports of globalization (see Sheffied, Korotuger and Grinin, 2013).

At the national level, the cross cutting issues of climate change require an approach to public governance that acknowledges a number of legal and institutional arrangements working severally to achieve the objective of adaption and mitigation. In Nigeria, such arrangement is not far-fetched. First and foremost, the Constitution as the national legal order of the Federal Republic recognizes the imperative of protecting and improving the environment and therefore has made provisions for it (ELRI, 2011). Three sections of the constitution deserve mention here, namely, Section 20, Section 33 and Section 34. Section 20 imposes on the Nigerian State the responsibility to improve and protect the air, land, water, forest and wildlife of the nation. Sections 33 and 34 on fundamental human rights to life and human dignity respectively, have also been linked to the need for a healthy and safe environment as conditions to attain these rights (ELRI, 2011). Apart from these constitutional provisions, there are 26 extant laws and regulations on environmental protection and management in Nigeria. These laws and regulations cover environmental issues such as impact assessment, harmful waste, oil and gas, endangered species, aquatic life, nuclear radiation, water resources etc. (see elri-ng.org). Prominent among these laws is the National Environmental Standards and Regulations Enforcement Agency Act, 2007 (NESREA Act). The Act provides 
a comprehensive legal framework for compliance enforcement to all existing laws and regulations relating to the environment. The Act was amended in 2018 to strengthen the NESREA legal regime on the environment. Section 2 of the Act Provides that: The Agency, shall subject to the Provision of this Act, have responsibility for the protection and development of the environment, biodiversity conversation and sustainable development of Nigeria's natural resources in general and environmental technology, including coordination and liaison with relevant stakeholders within and outside Nigeria on matters of enforcement of environmental standards, regulations, rules, laws, policies and guidelines.

To complement the foregoing legal regime on the environment, there are seven prominent non-governmental organizations operating in Nigeria with diverse interests on environmental protection and management. They are: (1) Nigerian Conservation Foundation, with interest in nature conservation; (2) Nigerian Environment Society, with interest in environmental protection; (3) Friends of the Environment, with interest in environmental awareness campaign; (4) Recycle, with interest in waste disposal management; (5) Obudu Conservation Centre, with interest in education and public enlightenment for the protection and restoration of wildlife and wildland; and (6) Centre for Climate Change and Environmental Studies, with interest in combating climate change through research on the environment (see http://www.ngeranngo.com). There is also the Environmental Law Research Institute (ELRI), with interest in the protection of the environment and promotion of human health. The writer has argued elsewhere that the open society engendered by liberal political conditions has provided the impetus for a variety of non-state actors to engage with specific public policy that is consistent with their interest. This engagement has taken many forms, including, but not limited to voluntary participation in public service delivery (Ozohu-Suleiman, 2019). Thus, the increasing number of non-governmental organizations with interest in environmental policy is a strong indication that public governance for climate action is essentially collaborative. This collaborative effort is helping to furnish citizens awareness of the interdependence between their well-being and the environment in which they live.

On the energy sector, it is observed that government policy is focused mainly on the development and regulation of the power sector, bearing in mind its relevance to climate change. To this end, a comprehensive reform of the power sector was commenced in 2001. The reform privatized the National Electric Power Authority (NEPA) and unbundled it into seven generation companies, one transmission company and eleven distribution companies. However, the transmission and system operation remain under the control of the government. While the cost associated with high voltage and grid expansion is borne by the government, electricity generation capacity and distribution are thrown open to private investors (Ogunleye, 2016). The reform of the power sector also involves a significant number of national institutions and non-governmental stakeholders. There are 17 of such national institutions and a handful of stakeholders outside the government. This is in addition to the numerous faculties of engineering in many universities scattered all over the country. Some of these universities have established collaboration with the Energy Commission of Nigeria (ECN) on energy research, development and advisory services. Table 3 below provides a list of selected national institutions and non-governmental organizations and their roles in the 
power sector. It is assumed that these roles are very critical to the successful implementation of power sector reform.

Table 3. Selected list of National Institutions/Non-Governmental Organizations and their role in the new power-sector regime

\begin{tabular}{|c|c|c|c|c|}
\hline $\mathbf{S} / \mathbf{N}$ & National Institutions & Role & NGOs & Role \\
\hline 1. & Fed. Ministry of power & $\begin{array}{l}\text { Development of } \\
\text { electricity generation }\end{array}$ & $\begin{array}{c}\text { Council for Renewable } \\
\text { Energy }(\mathrm{CREW})\end{array}$ & $\begin{array}{c}\text { Promote the } \\
\text { development of } \\
\text { renewable energy. }\end{array}$ \\
\hline 2. & $\begin{array}{c}\text { Nigeria Electricity } \\
\text { Regulation Commission } \\
\text { (NERC) }\end{array}$ & $\begin{array}{l}\text { Monitoring and } \\
\text { regulation of the } \\
\text { electricity industry }\end{array}$ & $\begin{array}{c}\text { Manufacturers } \\
\text { Association of Nigeria } \\
\text { (MAN) }\end{array}$ & $\begin{array}{c}\text { Formulate Policy for } \\
\text { efficient energy } \\
\text { environment for } \\
\text { Manufacturers. }\end{array}$ \\
\hline 3. & $\begin{array}{c}\text { Rural Electrification } \\
\text { Agency (REA) }\end{array}$ & $\begin{array}{l}\text { Coordinate rural } \\
\text { electrification. }\end{array}$ & $\begin{array}{l}\text { Nigerian Society of } \\
\text { Engineers (NSE) }\end{array}$ & $\begin{array}{l}\text { Promote and regulate } \\
\text { standard of formal } \\
\text { engineering education. }\end{array}$ \\
\hline 4 & $\begin{array}{c}\text { Electricity Management } \\
\text { Services LTD. }\end{array}$ & $\begin{array}{l}\text { Support Services in } \\
\text { the areas of } \\
\text { production and } \\
\text { delivery of Power. }\end{array}$ & $\begin{array}{c}\text { Green Building Council } \\
\text { of Nigeria }(\mathrm{GBCN})\end{array}$ & $\begin{array}{c}\text { Provide rating system } \\
\text { for sustainability of } \\
\text { building. }\end{array}$ \\
\hline 5 & $\begin{array}{c}\text { National Power Training } \\
\text { Institute. }\end{array}$ & $\begin{array}{l}\text { Training of Technical } \\
\text { Power Professionals. }\end{array}$ & $\begin{array}{l}\text { Nigerian Institute of } \\
\text { Architects (NIA) }\end{array}$ & $\begin{array}{c}\text { Regulate the practice of } \\
\text { architecture. }\end{array}$ \\
\hline 6 & $\begin{array}{l}\text { Fed. Ministry of } \\
\text { Environment. }\end{array}$ & $\begin{array}{l}\text { Foster renewable } \\
\text { energy and energy } \\
\text { efficiency. }\end{array}$ & $\begin{array}{l}\text { Nigerian Institute of } \\
\text { Building (NIOB) }\end{array}$ & $\begin{array}{l}\text { Provide managerial, } \\
\text { technical and } \\
\text { administrative capacity } \\
\text { in building } \\
\text { construction. }\end{array}$ \\
\hline 7 & $\begin{array}{l}\text { Energy Commission of } \\
\text { Nigeria }(\mathrm{ECN})\end{array}$ & $\begin{array}{c}\text { Research, } \\
\text { development and } \\
\text { advisory services on } \\
\text { energy. }\end{array}$ & & \\
\hline 8 & $\begin{array}{c}\text { National Agency for } \\
\text { Science and Engineering } \\
\text { Infrastructure (NASENI) }\end{array}$ & $\begin{array}{l}\text { Local manufacturing } \\
\text { of renewable energy } \\
\text { technologies }\end{array}$ & & \\
\hline 9 & $\begin{array}{c}\text { Nigerian Bulk Electricity } \\
\text { Trading PLC. }\end{array}$ & $\begin{array}{l}\text { Purchase and resale } \\
\text { of electricity services. }\end{array}$ & & \\
\hline
\end{tabular}

Source: Author's Compilation, 2020

\section{Discussion}

In discussing Public Governance for climate action in Nigeria, four interrelated indicators are key to measurable mitigation and adaption. These are; energy provision, food security, 
pollution control and reforestation. As hinted earlier in the paper, these indicators have generated wide ranging issues to rethink existing legal and institutional frameworks for a robust public governance for climate action. It is unarguable that decades of energy deficit stand tall between Nigeria and her development aspirations. As the struggle to fix the energy requirements of the largest economy in Africa subsists, the world has moved on to embrace more ambitious development aspirations. For example, the Fourth Industrial Revolution (41R) marks another epochal turning point in human civilization. Mankind is on the threshold of a revolution characterized by "the fusion of digital, biological, and physical worlds, as well as the growing utilization of new technologies such as artificial intelligence, cloud computing, robotics, 3D Printing, the Internet of things, and advanced wireless technologies, among others" (Ndungu and Signe, 2020). However, it is regrettable that Nigeria may not be able to harvest optimally from the gains of the 4IR because of huge deficit in the underpinning infrastructure. In other words, electricity, which constitutes a fundamental attribute of the Second Industrial Revolution (2IR), has not been accomplished in Nigeria. Thus, the ensuing information technology that characterized the Third Industrial Revolution (3IR) has created a digital divide between the advanced industrial economies and Nigeria - a condition precedent to the 4IR.

In addressing the energy crisis, the Nigerian government has embarked on a power sector reform. The aim is to achieve, among others, increase in power capacity delivery and access, increase in the share and efficiency of renewable energy generation, reduction in the cost of power along the value chain and mitigation of environmental impact of energy generation, transmission and distribution (Ikeme and Ebohon, 2005). However, one and half decades into the implementation of the power sector reform, significant access to electricity provision has not been achieved owing to a number of challenges, some of which include poor funding of the power sector arising from dwindling government revenue, government loss of the moral justification to increase electricity tariff, structural problems such as shortage of gas supply for thermal plants and the use of outdated and poorly maintained transmission network (Oladipo, Felix, Bango, Chukwu Emeka and Olawale, 2018). As part of government efforts to boost power generation, the 40 -year old Mambilla power project has been resuscitated. The project which is estimated to cost USD5.8billion, will generate $3.05 \mathrm{GW}$ of hydro-electricity. When completed, the project will be the largest power generating installation in the country, and one of the largest hydro-electric power stations in Africa (www.nsenergybusiness.com). Under the bilateral cooperation, the Chinese Exim Bank will provide $85 \%$ of the fund (amounting to USD4.93billion), while the remaining $15 \%$ will be provided by the government of Nigeria. Moreover, the bilateral cooperation between Nigeria and Siemens of Germany on power generation, transmission and distribution under the Presidential Power Initiative (PPI), that came into effect earlier in the year, may well provide the break from what has become an intractable problem. The deal involves a counterpart funding by Nigeria to the tune of N8.64 billion, which represents $15 \%$ of the USD2 billion project, with the remaining $85 \%$ to be funded by a consortium of banks (nairametric.com). The project aims to upgrade operational capacity from the current $4,500 \mathrm{MW}$ to $25,000 \mathrm{MW}$ through an implementation plan spanning three phases. This will begin with pre-engineering works for transmission, distribution and Meter Data Management System (MDMS). Below is a 
summary of the project:

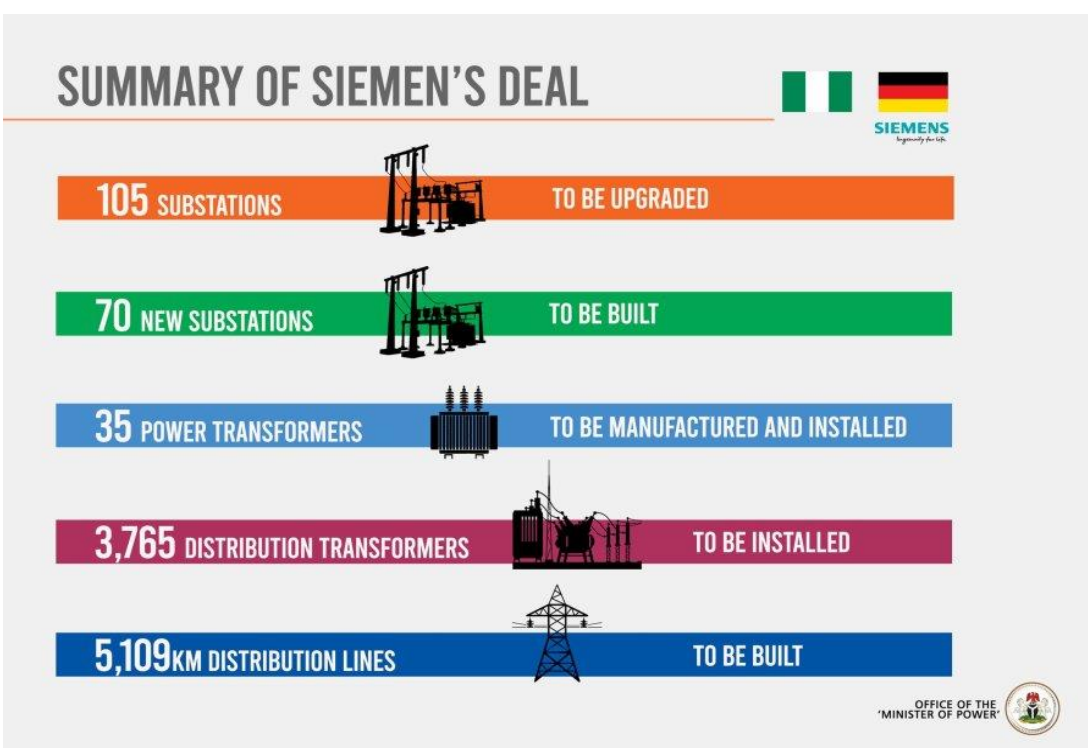

Source: https://switchnigeria.com

Food security is another key area of policy intervention to mitigate the impact of climate change. In Nigeria, there are two major concerns, namely, preserving environmental resourcefulness through reforestation, drought/desertification and flood control on the one hand, and energy provision to facilitate logistics in the agricultural value chain (e.g. warehouse, storage and processing systems). Since drought/desertification and flood are concrete manifestations of climate change, mitigation measures underpinned by efficient energy will sustain environmental resourcefulness for food production. Within the overall framework of protecting the environment, the Nigerian government has developed a national action plan to combat drought/desertification. The salient elements of this plan are: (i) Promoting sustainable agricultural practices and management of water resources including water harvesting and inter-basin transfer; (ii) Encouraging individual and community participation in viable afforestation and reforestation program using tested pest and drought-resistant and/or economic tree species; and (iii) Inventorizing degraded lands, and implementing preventive measures for lands that are not yet degraded or which are slightly degraded (FMOE, 2009:18).

On flood control and mitigation, the National Emergency Management Agency (NEMA) has developed a framework for emergency preparedness and response risk reduction capacity. This policy framework is consistent with the United Nations Hyogo Framework of Action on Disaster Reduction 2005-2015. The NEMA framework addresses four priorities, namely: (i.) Make disaster risk reduction a policy priority through institutional strengthening; (ii) Identify, assess and monitor disaster risks and enhance early warming; (iii) Use knowledge, innovation and education to build a culture of safety and resilience at all levels; and (iv) Reduce underlying risk factors (NEMA, 2012). However, the widespread and intense flooding across the country in the last five years suggest that these priorities have not been sufficiently 
operationalized for flood control and mitigation. As a consequence, changes in rainfall pattern have triggered unpredictable local seasonal and annual water imbalance with severe impact on agricultural crop production. The Nigerian Red Cross has reported the human and material losses associated with flooding in recent times (floodlist.com/Africa/nig).

On pollution control, the NESREA, pursuant to its mandate, has developed a comprehensive regulatory framework. The regulations cover an extensive range of issues on environmental protection. The framework aims to prevent and minimize pollution from all operations and ancillary activities that are harmful to the environment. To this end, provisions are made for the prevention and control of effluent, emissions and noise. For example, regulation 15 (1) States that, No company shall discharge effluent onto land, into a water course or into water body unless the company ensures that parameters of the effluent do not exceed the permissible limits set out under schedule 1 and IV to these regulations. On emission, regulation 20 (3) states that, No company shall burn, or permit to be burned, light fuel oil containing over $0.5 \%$ Sulphur by weight as fired in an existing source or a new source (NESREA, 2009).

On the issue of gas flaring, there have been several legal regimes that appear unenforceable. These are: (1) The Gas Flaring (Prohibition and Punishment) Act, 2009, with a gas flaring time limit fixed for $31^{\text {st }}$ December, 2010; (ii) The Petroleum Industry Bill has set a gas flaring deadline for 2012; (iii) The Gas Flaring Prohibition and Punishment Bill, 2016, set the time limit for gas flaring to December, 2016; (iv) The new Petroleum Industry Governance Bill, 2017, outlawed gas flaring; and (v) The Gas and Associated Gas Re-injection (Amendment Bill) that is pending in the National Assembly (Olujobi, 2020). Lack of political will coupled with the inability of government to divorce vested interests from the governance of downstream sector of the petroleum industry partly account for these ineffectual legal regimes.

Although Nigeria is blessed with abundant forest reserves, the ecological zones have been largely depleted by a combination of factors that are closely linked to climate change. The most instructive of these factors is household dependence on fuel wood for energy which accounts for about $3.3 \mathrm{~m}^{3}$ consumption of wood in a year (EU: NESP, 2015). While access to renewable energy remains the most viable option to preserve forest resources, reforestation is a compelling remedial action to regenerate the ecological zones in Nigeria. According to Akpan-Ebe, (2017), reforestation which is the process of restocking the forest so as to ensure continuous supply of timber and other forest produce in a sustainable basis, takes the natural regeneration and/or artificial regeneration methods. Needless to go into the technical details of these methods, Nigeria has at various times adopted enrichment planting, which is a combination of natural and artificial methods. To this end, the government of Nigeria with the support of stakeholders on environmental protection has launched a massive tree planting campaign. The Federal Ministry of Environment has commenced a nationwide program to plant 35 million enrichment trees in 2020. This program is being implemented alongside a Task Force in the Department of Forestry of the Ministry to monitor tree felling, wood processing and marketing (www.premiumtimeng.com). The Rural Environment Empowerment Initiative (TREE) has also embarked on a long term afforestation and 
sustainable forest management program. The aim is to promote public enlightenment on the need to mitigate the negative consequences of climate change caused by indiscriminate felling of trees and depletion of forest resources (treeinitiativeng.org). To this end, the following program to plant and nurture 10 million trees by the year 2025 are in place: (i) One Student One Tree Project (OSOTP); (ii) National Shea Tree Restoration Advocacy Program (NASTREP: 2019 - 2025); (iii) Commemoration of the International Day of Forest; and (iv) Local Communities Tree Planting Campaign.

\section{Conclusion and Recommendations}

Environmental concerns raised by climate change in Sub-Saharan Africa will for a long time remain a dominant issue in the development discourse of the sub-region. This is because understanding the impact of climate change on the environment is an important step for any policy analysis of public governance for climate action. Regrettably, current and future adaptive capacities of countries like Nigeria are largely influenced by the level of technological development. Incidentally, energy provision and access to it is a significant parameter for measuring the level of technological adoption. Thus, the high point of the general policy debates is that the cost of climate change constitutes an extenuating factor in the development process of the supposedly largest economy in Africa. In specific terms, this paper has synthesized the real and potential cost of climate change on environmental resourcefulness in Nigeria. In doing this, it focused on the huge deficit in electricity infrastructure and its implications for food security and the resilience of the environmental resources to sustain livelihood. However, as a compelling item in the governance agenda, there are a host of legal and institutional frameworks on state response to climate change. These frameworks are examined as part of the overarching objective of the paper to assess the capacity of the Nigerian state to contain the menace of climate change.

In the final analysis, two issues dealt with in the paper, requires a rehash. They are; (i) the multinational framework of intervention, and (ii) building state capacity for climate action. The former helps to generate ideas to inspire and facilitate consensus across national boundaries, and also create platform for global partnership. However, this multinational framework does not furnish a one size fit all concrete mitigation and adaptation. Therefore, building state capacity requires that national governments must develop the resilience to confront climate change. Thus, differences in the level of development across national boundaries will ultimately determine the scope and quality of public governance for climate action. For Nigeria, the parlous governance situation has further challenged state capacity for climate action. This is particularly evident in what is fast becoming an intractable energy crisis. Be that as it may, there is an increasing recognition of the influence of climatic conditions on the quality of life. While according priority to the place of electricity infrastructure, public governance for climate action must take into account other pertinent factors in the cross cutting issues of environment and development. In the light of augments advanced, observations made and issues discussed, the following recommendations are put forwards: 
i. There is an urgent need for government to bridge the huge discrepancy between installed generating capacity and actual output of electric power. This will require the provision of transmission and distribution infrastructure to facilitate the efficient delivery of power to end-users. Although funding is an issue, the government can explore the option of Public-Private-Partnership (PPP) to boost investment in transmission and distribution infrastructure.

ii. The bilateral cooperation between Nigeria and Siemens of Germany on power generation, transmission and distribution under the Presidential Power Initiative should be pursued and implemented to its logical conclusion. Apart from the predictable quantum improvement in power generation, investment in transmission and distribution value chain will generate multiplier effects such as job creation and stimulate the circular flow of income.

iii. The existing policy framework and legal regimes on air, land and water pollution control, though, imbued with laudable objectives, are lacking in effective implementation. This is especially the case with the numerous laws on gas flaring. The time has come for government to demonstrate commitment to the enforcement of these legal regimes as part of public governance for climate action.

iv. The implementation of the Mambila hydro-power project should be pursued with the commitment and forthrightness it deserves. The geo-spatial survey and compensation to affected communities should be fast racked to enable the project commence before the close of the year 2020 as scheduled.

v. Relevant institutions of the Nigerian government should sustain commitment to restocking the forest by providing incentives to drive the process of natural and artificial regeneration. This process should be in tandem with an extensive programme of public enlightenment to arrest traditional practices that are harmful to environmental sustainability.

\section{References}

AFDB (2020). African Economic outlook 2020: Developing Africa's workforce for the future. (Source: https://www.afdb.org/en/news-and-events/press)

Africa Energy outlook, (2019). (Source: https://www.iea.org/africa).

African Development Bank.

(2012).

http://afdb.org/en/countries/western-africa/Nigeria/infrastructure-and-growth-in-Nigeria-an-a ction-plan-for-strenghtened-recovery/.

Ajugwo, A.O. (2013). Negative Effects of Gas Flaring: The Nigerian Experience, Journal of Environmental pollution and Human Health, Volume 1 issue No1.

Akpan-Ebe, I. N. (2017). Reforestation in Nigeria: History, current practice and future perspectives. Reforesta, (3), 105-115.

Akpan-Ebe, I. N. (2012). Recovery Potential of Nigeria's Rainforest Ecosystem, in Etim, L 
and Oribhahor, B. (Eds), Current Issues in Sustainable Tropical Agriculture, Faculty of Agriculture, University of Uyo.

Nigeria Economic Outlook (2020). (Source: https://bloomberg.com).

Nigeria Economic Outlook (2020). (Source: https://ceicdata.com).

Environmental Law Research Institute (ELRI) (2011). A Synopsis of Laws and Regulations on the Environment in Nigeria. (Source: www.elri-ng.org)

European Union: Nigeria Energy Support Program (2015). “The Nigerian Energy Sector: An Over View with Special Emphasis on Renewable Energy, Energy Efficiency and Rural Electrification" (Source: www.ecowrex.org)

Federal Ministry of Environment, National Action Program to combat Desertification (Source: http://knowledge.unccd.int).

Federal Ministry of Environment (2018). National Drought Plan (source: http://knowledge. Unccd.int)

Federal Republic of Nigeria (2009) NESREA, National Environmental (food, Beverages and Tobacco Sector) Regulations (official Gazzette).

Federal Republic of Nigeria (2017). Agricultural Promotion Policy (APP) "Green Alternative," Factsheet (Source: nssp.ifpri.info/files/2017/12/2016-Nigeria...Policy)

Floodlist in Nigeria (2019) (Source: https://Floodlist.com/Africa/Nigeria)

Hassan, A. G., \& Oloke, D. (2019). Problems of Drought and its Management in Yobe State, Nigeria, Journal of Weather and Climate Extremes, Volume 23.

Ikeme, J., \& Ebohon, O. J. (2005). Nigeria's electric power sector reform: what should form the key objectives? Energy Policy, 33(9).

Mgbemene, C. A., Nnaji, C. C., \& Nwozor, C. (2016). Industrialization and its Backlash: Focus on Climate Change and its Consequences, Journal of Environmental Science and Technology, 9(4).

National Environmental Standards and Regulations Enforcement Agency Act (NESREA), 2007 (Source: http://www.nesrea.gov.ng)

Ndung'u, N., \& Signe, L. (2020). The Fourth Industrial Revolution and digitalization will transform Africa into a global powerhouse, in a Report on Capturing the Fourth Industrial Revolution: A regulation and national agenda (source. www.brookings.edu).

NEMA, (2012). Emergency Preparedness and Response (EPR) Disaster Risk Reduction (DRR) capacity Assessment (source:www.cadri.net).

Non-Governmental Organizations on Environment (Source: http://www.nigerianngo.com)

Nwodim, O. (2016). The 2012 Flood and Government Policy Response in the Niger Delta, Journal of Political Science and Leadership Research, 2(2). 


\section{Macrothink}

Journal of Public Administration and Governance ISSN 2161-7104 2021, Vol. 11, No. 2

Ogunleye, E. K. (2016). Political Economy of Nigeria Power Sector Reform, WIDER working paper 2016/9, United Nations University, World Institute for Development Economics Research (Source: wider.unu.edu).

Oladipo, K., Felix, A., Bango, O., Chukwuemeka, \& Olawale, F. (2018). Power Sector Reform in Nigeria: Challenges and solution, IOP conference theme: Materials Science and Engineering (Source: iopsaence.iop.org).

Olujobi, O. J. (2020). Analysis of the Legal Framework Governing Gas flaming in Nigeria's Upstream Petroleum Sector and the Need for Overhauling, social sciences, 9, 132; doi:10.3390/socsc19080132 (Source: https://www.mdpi.com).

Oyedepo, S. O. (2012). Energy and Sustainability in Nigeria: The Way Forward (http://www.energsustainsoc.com/content/2/1/15)

Ozohu-Suleiman, A. (2019). The State, Market and Citizens Sector in Post-Transition Societies: Towards an Inclusive Framework of Governance in Nigeria. Advances in social science and culture, 1(2).

Pollitt, C. (2016). Debate: Climate change - the Ultimate Wicked Issue. Journal of Public Money \& Management, 36(2), 78-80.

Punch Newspaper. (2017). Heavy use of generator puts Nigeria's climate plans in jeopardy. December, 18 (Source: http://punchng.com).

Punch Newspaper (2020). "Gas flaring in Nigeria”, January, 1 (Source: http://punchng.com).

Sheffield, J., Korotayex, A., \& Grinin, L. (2013). Globalization: Yesterday, Today and Tomorrow, Litchfield Park: Emergent Publications 3810N 18815 Avenue

The African Union Commission (2015). Africa Agenda 2063, First Ten-year Implementation Plan 2014-2023 (Source: http://nepad.org/publication/agenda).

The Guardian Newspaper (2019). "Adaptation of Agricultural Strategies to Extreme Climate in Nigeria" (Source: http//m.guardian.ngs $>$ tag drought).

Umana, K (2019). Incidence, Causes and Effects of Flooding in Nigeria (Source: http://research cyber.com/flooding).

UNEP (2017). Environmental Assessment of Ogoniland (Source: http://www.unenviroment .org).

UNEP (2018). Putting Environment at the Heart of People's Lives, A United Nations Environment Annual Report. (Source: https://reliefweb.int/report/world/un-environment-2018-annual-report-putting).

United Nations Framework Convention on Climate Change (UNFCCC) (1992). Climate Change: Impacts, Vulnerabilities and Adaptation in Developing Countries. (Source: www.preventionweb.net )

United Nations (2015). Sustainable Development Goals (SDGs) (Source: 
https://www.who.int/mental_health/suicide-prevention/SDGs/en).

USAID Power Africa in Nigeria, (2020). https://www.ngfcp.gov.ng

Vanguard Newspaper (2014). "Nigeria records over 10,000 deaths through 'generator fumes" (Source: Vanguard.com/2014/08).

World Bank (2020). Nigeria-Pubdocs. worldbank.org.

Worldometer (2020). Population of Africa (https://www.worldometers.info)

\section{Copyright Disclaimer}

Copyright for this article is retained by the author(s), with first publication rights granted to the journal.

This is an open-access article distributed under the terms and conditions of the Creative Commons Attribution license (http://creativecommons.org/licenses/by/4.0/). 